\title{
The absentee spouse phenomenon and spousal coping strategies in Ibadan, South-Western Nigeria
}

\author{
Olayinka Akanle ${ }^{1}$, Aderonke Omotayo Adebayo \& Dauda Busari \\ Department of Sociology, Faculty of the Social Sciences, University of Ibadan, Nigeria.
}

\begin{abstract}
Major incentives for marriage and family life are cohabitation, companionship, control economics and regular coital relationships for both procreation and pleasure. When spouses absent from home over a prolonged repeated period, it poses threat to expectations of family relations with implications for population and society. It is against this backdrop that this article examined the Determinants of Absentee Spouse Phenomenon and Spousal Coping Strategies in Ibadan, South-western Nigeria. Primary (questionnaires, IDIs and KIls) and secondary data were gathered. Findings revealed that ASP is becoming rampant in Nigeria and involves both men and women; but mostly men within the framework of traditional African masculinity and breadwinnerism. Sixty-eight percent (68.1\%) of the respondents maintained main cause of ASP is economic (employment and business). The outcomes of the ASP on the children, the spouses, the marriage as well as the spousal coping mechanisms were engaged in this article.
\end{abstract}

Key words: Absentee spouse, modernization, Ibadan, Nigeria.

\section{Résumé}

Principales incitations pour le mariage et la vie familiale sont cohabitation et camaraderie, contrôle l'économie et coïtale ordinaire relations pour les deux la procréation et le plaisir. Quand le conjoint absent du foyer pendant une longue période répétées, il pose menace d'attentes des relations familiales avec des implications pour la population et la société. C'est dans ce contexte que le présent article examine les déterminants du vote des absents phénomène conjoint conjoint et stratégies d'adaptation face à lbadan, dans le sud-ouest du Nigeria. Primaire (questionnaires, IDIs et KIls) et les données secondaires ont été collectées. Les recherches ont révélé que ASP est à l'état endémique au Nigéria et implique à la fois les hommes et les femmes; mais surtout des hommes dans le cadre des traditionnelles africaines et la masculinité breadwinnerism. Soixantehuit pour cent ( $68, I \%)$ des répondants ont maintenu cause principale de l'ASP est économique (emploi et affaires) .Les résultats de l'ASP sur les enfants, les époux, du mariage ainsi que le conjoint les mécanismes étaient engagés dans le présent article.

Mots clés: conjoint des absents, modernisation, Ibadan, Nigéria.

\section{Introduction}

A remarkable form of family life is forcefully emerging and reverberating in Nigeria. Nigeria, like many other Sub-Saharan countries, is experiencing an ascendancy of spousal absenteeism that is very definitive. Not that spouses working away, and absenting, from home is totally new and strange in Africa and Nigeria. In fact, it is nearly a norm and a critical part of the traditional agricultural and pastoralist African socio-economic systems where spouses go to farms and tend animals; go on long distance trade, warfare, diplomacy and pilgrimage (see Olutayo and Akanle, 2009; 2007). Africans have thus moved and worked away from home down the ages for various reasons. This is why such names as Abidemi (name given to children born in absence of fathers) among the Yoruba of south-western Nigeria exist to epitomize absence of a spouse (usually the father) even during child birth as an example of abandoned key family responsibilities. Spousal absence is therefore indicative, and punctuates African culture and existences, which somewhat situate the disposition and orientation in contemporary forms as modern and western cultural developments are infused into the subsisting traditional culture.

As people contribute to the emerging modern economy, with the acquisition of requisite modern skills and education, they gravitate more towards the epicentre of modern employment and general economic activities regardless of distance from home in economies driven by more rationality and income. It is thus possible to conceive of the ascendancy of Absentee Spouse Phenomenon (ASP), defined here as repeated absence of a spouse from home for two weeks or more, as associates of modernization, urbanization, westernization, industrialization and enhanced rationality. The basis for this current definition and boundary was both empirical and contex-

I. Corresponding author: e-mails: yakanle@yahoo.com,yk.akanle@mail.ui.edu.ng, Phone: +234-8028492216 
tual. The sense of loneliness and feeling of absence become problematic at regular and recurrent two weeks.

Hence, different from the primordial African societies where people moved from home only intermittently and seasonally usually with their spouses and family, in certain instances, the current spousal absenteeism is more prolonged, regular and bound to have huge consequences for the population and overall development of Nigeria. Hence, when a season of movement in the primordial times could even be longer than 2 weeks as could be verified with the movement of Fulani pastoral nomads who often left the women, children and weak in temporary settlements while taking their cattle in search of water and grazing lands and they return after the season when water and graze may have reestablished in their place of origin, such societies/ groups, however, had strong traditional norms, values, systems, strategies and tactics that controlled the family and spouses unlike within the current/ contemporary and globalized/westernized contexts (see Desta, 20I3).

Unfortunately however, not much attention has been paid to this phenomenon in the research domains of the country and even the Sub-region. Even in the global academy, there is some measure of indifference relative to the recent phenomenon perhaps ASP has come to be accepted as a normal part of the modern/postmodern life without sufficient appreciation of its possible aftermath. Generally, investigations into this area of study is actually few and this is an aspect of social life that is gradually becoming a norm in society yet social scientists are failing as students of society to begin to understand it so as to understand its possible effects as mandated by the founding fathers of Sociology for example.

The few related studies globally are both very old and distant from the socio-economic and demographic specificities of Nigeria and Sub-Saharan Africa. For example, Biller and Meredith in 1972 researched the "Invisible American father" in Sexual Behavior. Even though this work has been recognized as a pioneering one in this area of research, it is both dated and extra-contextual. Similarly, while Sauer's "Absentee Father Syndrome" (1979) came a bit later, it is also dated and extra-contextual. These first two works were also partial and not comprehensive as they captured the experiences of only one spouse. Hence, only Enel, Lagarde and Pison's "The evaluation of surveys of sexual behaviour: a study of couples in rural Senegal" in Health Transition Review (1994) was in the Sub-region. Yet, the Enel, Lagarde and Pison's (1994) was more health oriented, also dated and focused on sexual act of coital frequency. This article is necessary to further and better com- prehend the crucial manifestations of ASP and fills important lacunae in terms of periodization, pattern, context and domains. This article does not only consider the determinants but also context and coping strategies within the problematic. Indicative research questions interrogated in this article are; what are the determinants of ASP? What are the outcomes of ASP on the children and spouses? And, what are the coping mechanisms available to the spouses involved in ASP?

Although the family is commonly seen as a very resilient system, it is also liable to stress (Patterson, 2002). The family today is mostly at the receiving side and end of strenuous forces as traditional values that hitherto held the family are threatened just as the structure comes under survival scrutiny. This is more so in the age of modernization, westernization, globalization and industrialization. This is why Nicholson (1997) engaged the notion of "traditional family" and "alternative families" to illuminate the continuities and discontinuities in the family formations and operations as the old interfaced with new realities of the modern world. For Nicholson (1997), the traditional family is "the unit of parents with children who lives together" and the bond connecting husband and wife is crucial as against the alternative family with weaker relationships between husband and wife and who do not necessarily live together even with children (Nicholson, 1997). This is also necessitated most times by reorganization in family work life as people work away from home especially beginning from the era of industrial revolution and reinforced in the $21^{\text {st }}$ century and most likely beyond as against what obtained in the pre-colonial Nigeria (Olutayo 1996).

This family-home-work distanciation has also contributed to the collapse of extended familiation. Even though Otite and Ogionwo, (2006) posited the collapse of the extended fimiliation and movement to the more popular western nuclear family model is gradual, the experience in Nigeria of late has been more than gradual but sporadic and this has contributed to the commonality of social problems like child labour or what Olutayo (1994) termed systemic working children; the involvement of youth in crime (both in rural and urban areas) and family disorganization among many other related social problems. This is why, Gottfredson and Hirschi (1990) maintained that ineffective child rearing/socialization leads to low self-control and low self-control increases the risk of delinquency in an individual. The development and commonality of these social problems should be expected since spouses leave supposedly joint responsibility of socialization to a spouse rather than both spouses. The case becomes more difficult when the absent spouse is the male in 
an extremely patriarchal society with huge and dominant male influence even in cases as ordinarily feminine as reproductive health, fertility and women centred contraceptives (see Isiugo-Abanihe, 2003).

In Nigeria, Olutayo and Akanle, (2007:54) observed that "there are issues that suggest a weakening in the family as an institution" and as extended family system is fast becoming a myth. Societies are more individual focused today as the nuclear family structure, and even single parenting is becoming popular regardless of the level of professed love within the family system as they confront difficult economic decisions in a poverty infested nation. Movement of people and urbanization are necessary corollaries of industrialization and industrialization can never be separated from modernity particularly as the world becomes globalized. In a related fashion, Findley and Williams, (I99I) submitted that locations have implications for work-related movements and the possibility of breaking away from traditional roles is greater in urban centres than rural particularly for married women (see also Rutayisire, Broekhuis and Hooimeijer, 2013). The case is however not totally different for men.

The same is also bound to be applicable to males who even find it easier to wriggle out of established norms and ethos of traditional family life as they face excruciating economic demands from the family and society at large. According to Hettige (1990), when spouses move for work-related reasons, they are found wanting in child care/socialization and the spouses become more predisposed to infidelity; two cases that mostly threaten the family and societal wellbeing most especially in the age of HIV/AIDS and a society without any social welfare services for delinquent children. Evidences suggest that family/ spouses working far from home in manner of absence account for high divorce rates/failed/ stressed marriages, fertility decline/fluctuations and general atypical family situations (See Sardon, 2000; Davidson and Moore, 1996 and Roussel, 1989).

Globalisation can have both positive and negative impacts on the family and literature has linked many recent challenges facing the family to globalization (Welfrid, 2007, Balogun and Olutayo, 2005-2006, Olutayo and Omobowale, 2006, Giddens, 2000). Globalisation gives rational and more critical forms to human thinking even within the family as they are exposed to hitherto distant values and norms including those inimical to family traditional belief systems even as the views of and orientation towards the family including roles and residency becomes globalized (Akanle, 20I la). Balogun and Olutayo (20052006) examined the effects of globalisation on the family from the period of colonial civilisation in Africa and maintained that relative to the family, Africans had to be re-civilised along capitalist line with effects on the family (see also Aderonkola, 2009, Cavanagh, 2008, Akande, 2006, Price and Kunz, 2003, Muehlenberg 2002). It is only when both parents are present and continuously/concertedly involved in child socialization that outcome can be well positive. In a situation where a spouse, especially the culturally determined dominant figure, is absent, the implications for socialization are huge.

Regrettably, there appears to be more single parent families today and many are due $a b$ initio to the ascendancy of ASP. Living in a single-parent and/or ASP family is a major predictor of delinquency as researches have clearly demonstrated that children from single-parent homes are more likely to be delinquent and achieve less in life (see Breivik, Olweus and Endersen, 2009, Eweoya, 2008, Mandara and Murray, 2006, Wu, 1996, Downey and Powell, 1993). Single-parent families, especially single-mothers, expect less achievement from their children, spend less time monitoring them and use less effective techniques to discipline them (Simons, Simons and Wallace, 2004, Bruce, 1995, Bruce, Lloyd, Leonard, Patrice and Duffy, 1995) unlike in families with the two parents cohabiting and father as the main and only figure stays (see also Gerald, 2008, Wark, 2000, Fagan, 1999, Balcom, 1998) and this is more understandable for Africa and Nigeria where masculinity is equated with control and authority.

ASP is framed within a blend of Modernization Theory (Rostow, 1953; 1960) and the Attachment Theory and Parental Alienation of Ludwig. F. Lowenstein (2008) in this article. Modernization Theory describes and proffers analysis and explanation of the processes of changes societies experience overtime as they attempt to develop. Modernization Theory (Rostow, 1953, 1960) was developed in quest to account for the nature and process of growth of underdeveloped societies as from traditional societies to modern developed societies as witnessed earlier in the west. In this light, the social structure of the African, Asia and Latin American societies must be replaced with the more modern western structures that are development enablers. It is within this premise that even the traditional family formation processes and family culture must be moderated to accommodate the modern economic systems including working away from home in the modern market driven and skill determined economic systems and processes. Since industrialization and even globalization are key components of the modern era, it is thus possible to account for the contemporary economic and family relations within the modernization prisms. Modernization theory has its roots in the late 1950s and early 1960s with pop- 
ularity in the 1970s as the developed world showed the development pathways to the underdeveloped south.

Modernization is commonly seen as a process yet a destination and this is why it has been variously criticised as Eurocentric, teleological and deterministic benchmarking development within the frameworks of developed Western Europe and North America (see Ritzer, 2008). There has been pluralisation of activities in the societies as social institutions become more developed and responsive to emerging modes of production in the current societies. There is thus separation of productive activities from the original social institutions unlike what obtained in the pre-colonial social formations and mode of productions. Particularly, in the other of modernization theory, there has been a major shift from agriculture to factories and modern office complex and the values are constantly in a state of flux and the Nigeria societies adapt to current modern and global realities determining needed skills and different social relations within the subsisting social formations and modes of production.

To cater for the grand and macro shortcomings and fixations of the modernization theory, a micro theory is needed. Attachment Theory and Parental Alienation (Lowenstein, 2008) comes handy and relevant in specially accounting for the consequence of ASP especially on the children and the family as a system. Attachment Theory and Parental Alienation gives explanation for children relationship especially close attachment to parents since childhood and accommodates the necessity of both parents to be present and attentive to their children. When parents and authority figures are not available to oversee their children development especially at the critical years, problems within the family now and later is inevitable. Even though it is commonly appreciated that child attachment to mother is important at the beginning, the theory appreciates the importance of attachment to fathers as well especially at later years and this is more the case in Africa where fathers ratifies family decisions as the traditional authority figures. According to Holmes (1993), Attachment Theory and Parental Alienation accepts the customary and traditional primacy of the mother as the main caregiver, but never trivializes the importance of fathers and fathers are even more likely to become principal attachment entities at early and later life if they give best and most of the care to the children. Ultimately, parental care is very important and both parents need to be present to perform this critical role for the ultimate good, development and population of the society even as they operate within the realities of modernization, industrialization, globalization and overall contempo- rary occurrences.

\section{Data and methods}

The study area was Ibadan, the capital city of Oyo State, in the South-western part of Nigeria. Ibadan has a population of 5,591589 (National Population Commission [N.P.C.] 2010). The city is cosmopolitan and among the most populous cities in Africa. It is also known to be among the most traditional cities in Africa, yet rapidly modernizing to accommodate the rate of growth and development of the $21^{\text {st }}$ century and beyond, especially as the city is very close to Lagos State - the fastest evolving Mega City in Africa. Although traditionally known for trading, agriculture, craftsmanship and public/private enterprises generally, Ibadan is the largest metropolitan geographical area, with total area of $1,189.2$ square $\mathrm{ml}$ $(3,080 \mathrm{~km} 2)$, density of $2144-5 / \mathrm{sq} \mathrm{m}(828 \mathrm{~km})$ and metro density 647.5/sq $\mathrm{ml}(250 / \mathrm{km} 2)$ (Ogunremi, 1998; Afolayan, 1994; and Areola, 1994).

There is a mix of economic and economic-aiding activities in Ibadan. These include; residential, industrial, commercial, rural and agricultural and social as well as educational institutions, such as University of Ibadan, Ibadan Polytechnic, among others. While there are both agricultural and industrial activities such as cassava, cocoa, Tobacco processing/Cigarette Manufacturing and flour-milling in Ibadan, new industries like the banks and telecoms are entering lbadan in unprecedented manner (Olutayo and Akanle, 2009). There is in-migration from other parts of Nigeria and the city is a family settlement for some workers in Lagos and Abuja. Accommodation is very expensive in Lagos and Abuja being among the most expensive cities in Africa. Yet, employment and business activities are mostly available in Lagos and Abuja as Lagos state is popularly known and accepted as the business and economic capital of Nigeria and Abuja the political and administrative headquarters.

Most companies and businesses either have their operating headquarters in Lagos/Abuja or have their key branches in the cities. It is considered cheaper to enrol children in Ibadan than Lagos and Abuja even if parents/spouses work in Lagos and Abuja. Also, many settle their families in lbadan and work in Lagos and Abuja because they believe Ibadan is peaceful and quiet just as it is comparatively more traditional and moralistic which makes it more suitable for proper child socialization. To generate data on ASP in Ibadan, a triangulation of quantitative and qualitative methods was used. The quantitative method was questionnaire, the qualitative method was in-depth interview (IDI) and case studies and the study population were both spouses at home (seden- 
tary spouses) and absent spouses. While we interviewed the sedentary spouses we also made efforts to interview the absent spouses to have a balanced understanding of the problematic Three hundred and fifty (350) copies of questionnaire were used for the study and they were administered through a combination of self-administration and researcher administration within Ibadan. The IDIs were used to complement data and were used to elicit information from ten (10) purposively selected spouses who have experienced ASP. 4 case studies were also conducted. All qualitative data collection instruments were researcher administered for consistency and comprehensive data gathering as many unspoken data must also be gathered and it takes the researcher to be able to best gather such data.

Snowballing (Non-probabilistic sampling technique) was used to select spouses who experience ASP. Although it is commonly argued that snowballing does not enable representativeness, according to Aldridge and Levine (200I), this type of sampling is most appropriate where there is no sampling frame, where examples of the people to be studied are rare or widely spread, and where the people of interest are likely to know each other and they will help the researcher find more relevant contacts (see also Bryman, 2004, Haralambos and Holborn 2008). While ASP is emerging, the proportion compared to the general population of lbadan is still widely dispersed and there is no sampling frame yet making this study pioneering and to drive research in this area. There has also not been any mapping and baseline survey on this category of people making a total/absolute population unavailable which also explains the choice of sampling method adopted in this study. It is commonly argued that the sampling technique can lead to redundant data gathering and skewed responses. These two problems were taken care of by limiting the numbers of people interviewed through an initial/first contact so as not to get repetitive and redundant data. Quantitative data was analysed with the aid of statistical software while qualitative data was analysed through content analysis, interpreted and presented as ethnographic summaries.

\section{Results}

Table I presents the socio-demographic characteristics of the respondents. The Table shows that $45.7 \%$ of the respondents were male. One could deduce that there were more male absentee spouses in the study area because more male are involved in distant jobs. The reason for more women at home than men can also be explained within the traditional role of women in Africa where women are expected to mostly stay at home to care for their children while men go out to source for the family. The age of the respondents indicated that $98.2 \%$ of the respondents' age were within the range of $21-65$ years, $0.6 \%$ were $<20$ years while $1.2 \%$ were above 66 years. This implies that majority of the respondents were within the active age of production in terms of economy and reproduction in terms of fertility and reproductive health.

Table I Distribution of respondents by socio-demographic characteristics

\begin{tabular}{llll}
\hline Socio-demographic characteristics & Categories & Frequency & Percentage \\
\hline Sex & Male & 160 & 45.7 \\
& Female & 190 & 54.3 \\
\hline Current Age & 220 & 2 & 0.6 \\
& $21-45$ & 244 & 72.8 \\
& $46-65$ & 85 & 25.4 \\
& $66+$ & 4 & 1.2 \\
\hline Ethnic Origin & Yoruba & 294 & 84.0 \\
& lgbo & 31 & 8.9 \\
& Hausa/Fulani & 12 & 3.4 \\
\hline Marital Status & Others & 13 & 3.7 \\
\hline Educational level & Married & 297 & 84.9 \\
& Divorced/separated & 15 & 4.3 \\
& Others & 38 & 10.9 \\
\hline Occupation & Primary & 26 & 7.4 \\
& Secondary & 80 & 22.9 \\
& Tertiary & 206 & 58.9 \\
& Others & 38 & 10.9 \\
\hline Monthly income & Self-employed & 92 & 26.6 \\
& Private company & 120 & 34.6 \\
& Civil servant & 134 & 38.8 \\
\hline & <N2I,000 & 45 & 15.7 \\
& N2I,000-N40,999 & 161 & 56.1 \\
& N4I,000-N60,999 & 60 & 20.9 \\
& N6I,000-N80,999 & 14 & 4.9 \\
& N8I,000+ & 7 & 2.4 \\
\hline
\end{tabular}


Ethnic group of the respondents showed that $84.0 \%$ of the respondents were Yoruba, $8.9 \%$ were Igbo, and $3.4 \%$ were Hausa, while $3.7 \%$ were other ethnic groups. Thus, majority of the respondents were Yoruba. This was because the study was undertaken in Ibadan, a predominant Yoruba city in the southwestern Nigeria even though also cosmopolitan. Their marital status showed that $84.9 \%$ of the respondents were married and in marriage, $4.3 \%$ were separated/ Divorced, while $10.9 \%$ put themselves in other marital status (for instance cohabiting but not legally married). The educational qualification shows that $7.4 \%$ of the respondents had primary education $22.9 \%$ had secondary education, $58.9 \%$ had tertiary education, while $10.9 \%$ are others form of education or no formal education. This implies that majority of the respondents are highly educated as they have higher educational. On occupation, $26.6 \%$ of the respondents were selfemployed, $34.6 \%$ were working in private company, while $38.8 \%$ were civil servants.

As suggested by the data on occupation, there was more salary earning absentee spouses in Ibadan. The average monthly income calculated showed that $15.7 \%$ of the respondents earned N0-20,999,
$56.1 \%$ N21, $000-40,999,20.9 \%$ N41, $000-$ $60,999,4.9 \%$ earned between $\mathbf{N} 61,000-80,999$, while $2.4 \%$ earned $\mathbf{N} 8 \mathrm{I}, 000$ and above. The people discussed with through IDIs were mostly 30 to 50 years of age and this is within the normal age of marriage in Africa. Moreover, they were all married.

From Table 2 below, it could be observed that as high as $68.1 \%$ of the respondents indicated economic activities were the major cause of ASP for them and generally in Ibadan. Only $9.8 \%$ attributed ASP to education while a far lower proportion (I.4\%) attributed ASP to health, and $5.8 \%$ accounted for ASP via religion. Spouses can be absent due to religion reason especially if the spouse is a full time clergy and transferred to another environment, and it is not in all cases that the other partner will be able to follow him or her due spouse employment, education, or business. Also religion can make people to be absent if they are attending theological school, in most cases people in theological school are not allowed to leave school environment any how like those in circular school. $14.9 \%$ are others category. Economic reason is however the most predominant determinant of ASP in Ibadan.

Table 2 Determinants of ASP in Ibadan

\begin{tabular}{ll}
\hline Determinants & Percentage \\
\hline Employment & 35.9 \\
Business & 32.2 \\
Economy Related Sub-percentage & 68.1 \\
Education & 9.8 \\
Health & 1.4 \\
Religion & 5.8 \\
Others specify & 14.9 \\
Total Percentage & 100
\end{tabular}

Findings in quantitative data were very much consistent with those of the qualitative components thus demonstrating high level of within and across data and methods consistency. Determinants of ASP found in qualitative data were economic reason of employment and business, and education respectively. According to a respondent who said:

My husband is usually absent from home. He is usually absent for a month. He has always been absent from home since we get married like four years ago. The cause of his absence is job distance. Where he is working is far from where we are staying, he works in Abuja while we reside in Ibadan. The problem is that most of the time people who reside in lbadan do not get jobs in this place due to lack of industries. So lack of job in the environment is the cause of most of the absentee spouse issue in the area.

(Married woman/IDI/32years/July 30, 2012/ Ibadan).

According to another respondent:

My wife is always absent from home. She is usually absent for like a month and sometimes two weeks. She started been absent precisely last year. The cause of her absence is in order to further her education. The reason for her absence is because she want to further her education and the school she got admission to is outside lbadan and it is all for the family well been.

(Married man/IDI/34years/August 24, 20I2/ Ibadan). 
For another man:

My wife is always at home, but I am always absent from home at least fortnightly. I always travel and it will last for a minimum of one week or more than that before I come back home. Like I said earlier I use to be absent for a minimum of one week or more than, at least two or three weeks at times. I think even before my marriage, I have always been absent from home and when I got married my wife even complain but since it is the nature of my job that demand for it, there is nothing I can do about it and she has been coping with it. The cause of the absence is nothing but the nature of my work. We run shift in my working place and at times urgent travelling will set in. I think factors that led to absent of spouse from home is due to employment, which is the nature of ones work. Also at times it may be due to financial incapability because you may say you want to meet up with this and that and in the process of doing that it may take you out of your environment.

(A married man/IDI /35years/September 28, 2012/lbadan).
A respondent also opined that:

I am always absent from home. At times a week and at times two weeks, before now I use to keep away for good three months from my family due to my employment. By the time I got married to my wife, the following week of our marriage, I travelled out for god three months. It is due to my employment.

(Married man/IDI/50 years/October I, 20I2/ Ibadan).

From the data above, it can be deduced that the main determinant of ASP is economic reasons of employment and business. While as much as $68.1 \%$ of respondents in the quantitative component claimed economic reasons, $70 \%$ of the IDIs also claimed economic reasons while only $30 \%$ claimed education.

\section{ASP and the children}

It is important to test how ASP impacts the challenges children face as only one parent is often left to handle them in the face of these daunting challenges facing children today. The results are displayed in Table 3.

Table 3 Distribution of ASP implications for the children

\begin{tabular}{|c|c|c|c|}
\hline ASP for children & Responses & Frequency & Percentage \\
\hline \multirow[t]{2}{*}{ Children academics and ASP } & Negative effect & 252 & 72.0 \\
\hline & Positive effect & 98 & 28.0 \\
\hline \multirow[t]{3}{*}{ Reasons } & $\begin{array}{l}\text { Two are better than one, discipline and proper } \\
\text { care }\end{array}$ & 225 & 90.4 \\
\hline & Financial support and psychological balance & 12 & 4.8 \\
\hline & $\begin{array}{l}\text { Parents serves as a role model and spiritual } \\
\text { support }\end{array}$ & 12 & 4.8 \\
\hline \multirow[t]{2}{*}{ Children, morality and ASP } & Positive effect & 132 & 38.0 \\
\hline & Negative effect & 215 & 62.0 \\
\hline \multirow[t]{2}{*}{ Children, peer influence and ASP } & Negative effect & 243 & 71.7 \\
\hline & Positive effect & 96 & 28.3 \\
\hline \multirow[t]{2}{*}{ Children, crime and ASP } & Negative effect & 206 & 61.5 \\
\hline & Positive effect & 129 & 38.5 \\
\hline \multirow[t]{4}{*}{ Reasons } & They are free to do whatever they like & 90 & 44.3 \\
\hline & Lack of discipline/ inadequate monitoring time & 89 & 43.8 \\
\hline & Mothers cannot take care of male children & 21 & 10.3 \\
\hline & The children are exposed to danger & 3 & 1.5 \\
\hline
\end{tabular}

Most of the respondents maintained that ASP negatively impacts children academic performance. Most believed this is because it is always better for the two parents to be present to instil discipline and 
dedication to academics in the children and also give them proper care. Few however also believed the presence of the two parents give more financial support and psychological balance to the children unlike the presence of only one parent. Also, few also believed spiritual and modelling supports can only be best provided when the two children are present. Hence, most of the respondents concluded that ASP negatively affected their children morally because the only parents usually around could not sufficiently cater for the children morally. The same pattern was discovered relative to coping with peer pressure by the children. Most parents (6I.5\%) also maintained that ASP influenced children involvement in crime because of sufficient parental disciplined occasioned by ASP and in the case of absent fathers, mothers alone cannot care for male children sustainable especially in line with disposition to violent and criminal behaviour.

According to a respondent:

The children do not really feel good, because when he is around he plays with them, take them out and buy things for them. The fear of the father is not always there, what I will ask them not to do and they will do it, if their father is around once he shouts at them they will quickly run away. They tend to play rough play and sometimes cry that I should open the door for them, so that they can go and play outside. They are always calm and free, instead of longing to go outside to play, their father play with them. They prove more stubborn and they don't always get what they want. Morally I try my best to discipline them when they do anything wrong, but the effect of their father absence will still be felt; I will need to shout and shout before they listen.
(Married woman/IDI /32years/July30 2012/ Ibadan).

According to another discussant:

During my absence from home the children are not always happy because my presence at home counts much in their daily living; whenever I am absent they feel the impact so much. They behave well under duress not as a result of their normal behaviour, but because of the fact that if they do not comply there may be discipline up on discipline, which could come from their mother, as a result of this, under duress they behave well. They are free to express their mind, they are to express themselves, what they need, and they feel happy. But whenever I am not at home they subject themselves to the condition they find themselves. They don't have free flow of relationship, then they just subject themselves to the situation and force themselves to comply.

(Married man/IDI/48 years/September 27, 2012/lbadan).

Based on the qualitative data conducted also, it could be observed that, majority of the respondents submitted that the children are not always happy during the absence of one of their parents. Children particularly recognize the firmness of the fathers in terms of discipline and this is why a discussant maintained that the children do not like their father been at home because they will not be free to play around. Majority of the respondents maintained the consequence of the absence on the children is that they miss their absent parent, while the majority also submitted that absence of spouse negatively affect children academically, financially and morally. The effects of ASP on spousal relationships are presented in Table 4.

Table 4 The likely effects of ASP on marriage or on the spouse

\begin{tabular}{|c|c|c|c|}
\hline $\begin{array}{l}\text { Effects of ASP on marriag } \\
\text { Spouse }\end{array}$ & Impact & Frequency & Percentage \\
\hline \multirow[t]{2}{*}{ ASP and Divorce } & Negative & 201 & 58.8 \\
\hline & Positive & $|4|$ & 41.2 \\
\hline \multirow[t]{4}{*}{ Reason } & Need for companionship & 83 & 42.8 \\
\hline & ASP separate couples & 37 & 19.1 \\
\hline & ASP leads to distrust & 53 & 27.3 \\
\hline & Lack of support and no love & 21 & 10.8 \\
\hline \multirow[t]{3}{*}{ ASP and Spouse Emotion } & Lonely & 260 & 75.8 \\
\hline & Happy & 17 & 5.0 \\
\hline & Indifference & 66 & 19.3 \\
\hline \multirow[t]{2}{*}{ ASP and Spouse's health } & Positive & 18 & 5.3 \\
\hline & Negative & 319 & 94.7 \\
\hline
\end{tabular}


From the table above, it could be seen that ASP impacts spouses directly and negatively just as it does to children living ASP families. Majority of the spouses facilitated (almost 60\%) insisted ASP leads to divorce because the main essence of marriage and living within families in the first instance is companionship. When this is lacking, the possibility of divorce is grave. Also, this is due to the fact that ASP separates couples, leads to mutual distrust, lack of support and absence of love; all main ingredients of stable marriages and families. ASP tackles the main crux and scaffolds of marriages and families. Overwhelming majority of souses $(75.8 \%)$ also maintained ASP leads to extreme loneliness while $19.3 \%$ claimed to be indifferent to their spouses' absence as they have come to accept their fate. This is however a dangerous attitude to family and marriage existences. In fact, $5 \%$ said they were happy for ASP. This is due to the fact this spouses now enjoys freedom they would otherwise have lost if their spouses were to be around. Also, they feel ASP has allowed their spouses to earn a living and provide for the family as against if the spouse had been around and unemployed. Unfortunately, nearly all the respondents (94.7\%) claimed ASP negatively affects their health. These findings were also vividly captured in qualitative data.

\section{According to a respondent during IDI:}

I am always lonely and bored. He does call me that he is missing me and feeling lonely and bored, he always wishes to be around. The consequence is that I do wish to see him and this result to thinking and some sickness. Absence of spouse can led to divorce because gap in communication can create a feeling of lack of care, also friends influence can also create problem (like involvement in infidelity). Absence of spouse can lead to extra marital affairs because sometimes the body will call for it, and if the woman or man is not the type that can caution herself/himself and use to it and the spouse is constantly not around people can consider finding an alternative. Absence of spouse affects health when the burden is too much and nobody to share your mind with, this can lead to thinking and will result to hypertension.

(Married woman/IDI/ 32years/July30, 20I2/ badan).

For another respondent:

I feel too lonely sometimes. Let me just leave it like that, you will not understand. She also feels very lonely. (Probe: how do you know that?) When we talk on phone, she will always tell me honey I miss you, honey I love you. From this you will know that something is happening. One of the consequences of my spouse on me is that emotionally it affects me, sometimes psychologically I am been affected. When your spouse is not morally ok and does not fear God, there is always a tendency for extra marital affairs, before you know it can lead to divorce. Sure, if she does not have the fear of God. One, if her moral back ground is not up to standard, it will surely lead to extra marital affair. There will be too much of pressure on the spouse that is available; this will definitely affect once health.

(Married man/IDI / 34years/August 24 2012/ Ibadan).

While all the discussants submitted that they do feel lonely, the absent spouse also feel the same and that the consequences of ASP is that it makes them think a lot, leads to divorce and extra marital affairs, has negative implications on their health, they did clearly admit that they were involved in infidelity because of the cultural value and implications of such act, but from the way the non-verbal communication and argots like efi yen sile (leave that), do you understand? You cannot understand it could be deduced that infidelity due to ASP exists. The reason for involving in infidelity in this case is not far fetch; spouses experiencing ASP tend to look for alternative avenues of satisfying their sexual and other emotional needs in the face of loneliness induced by ASP. This is consistent with the conclusion of Hettige (1990). To further understand the problematic, we investigated the coping mechanisms of the spouses.

\section{Coping mechanisms of spouses}

As many as $91.7 \%$ of the respondents indicated that they think spouses miss their husband or wife when he or she is not around, while $8.3 \%$ of the respondents indicated that they do not miss their husband or wife when he or she is absent. This implies that the majority of the respondents miss their spouses when they are absent. $18.0 \%$ of the respondents indicated that it requires the grace of God and reading of religious books like the Bible. Others cited: reading, watching television. In terms of coping sexually, $82.0 \%$ of the respondents indicated that it requires mutual understanding, trust, and love among the spouses, and self-discipline for spouses to cope with the absence of their spouse sexually. $34.9 \%$ of the respondents indicated that they cope with ASP emotionally through constant communication on phone and looking at his/her pictures and encouragement. $41.5 \%$ of the respondents also claimed they generally cope with ASP emotionally through self-disci- 
pline and the grace of God as well as devoting attention to children. It should be noted that such attention substitution will ultimately affect affection between the spouses. Little wonder some of the spouse earlier claimed they no longer miss their spouses. This is a danger signal and recipe for family instability.

A respondent expatiate during IDI:

He gives us money monthly and I try as much as possible to manage the money. Absence of spouse should not affect once moral if your moral up bringing is actually ok before you get married. So I have always been who I am when he is around or not. I am able to cope sexually, ones I am missing him I call him and we talk and talk and I will feel relieved. Also he comes home every month and even sometimes twice in a month. Though it has not been easy, but I have no choice. He is the bread winner of the family, I have no job yet and he that has is what we are using to sustain our self, so I have to cope. Absence or no absence does not affect my religious life, he is also a Christian, so we both pray, even sometimes we do have prayer and fasting for the family and everything will be done through phone. It has not been easy but God has been helping me.

(Married woman/IDI/ 32years/July30 20I2/ lbadan).

For another respondent:

In terms of finance, we cope by the grace of God, most of this things sometimes you don't even know the means where by God provide, you just see that the needs are been met. By the grace of God once you are morally ok there is no issue with coping when your spouse is not around. Once you have been brought up morally from childhood, teach a child in the way of God, when he or she grows up, he will not depart from it. On sexual need, anytime I need her, I just call on her and she will come. We communicate often so that gap is reduced. I am a Christian from childhood and well brought up in the way of the lord, so there is no problem with that. Domestically I am very good, so I don't have issues with that. I take care of my children myself.

(Married man/IDI/34years/August 24 2012/ lbadan).

The majority of the respondents cope with ASP through various means they have devised overtime. Such means included been discipline, resignation to faith, self-denial and rationalization, turn to religion and front loading of needs. As already indicated above, for those not so religious however, they engage in extra-marital affairs even when they will not openly and verbally divulge such culturally forbidden information publicly except when probed with expertise and observance and understanding of body language.

\section{Discussion}

The finding on determinant of ASP is consistent with those of Kunz, (20II), Balogun and Olutayo (20052006), Price and Kunz, (2003) and Muehlenberg (2002) who have discovered economic developments and necessities occasioned by globalization and modernity as the main causes of spousal and parental absence as spouses and parents are resocialized and "re-civilized" into the modern economic culture with implications for the family. This is also in line Olutayo and Akanle (2007) and Findley and Williams, (1991) findings that there has been a shift from the traditional survival mechanisms of families and breadwinners as navigate the industrial societies. As people are forces to acquire newer skills through the formal education, as could be seen in the educational background of the respondents, they develop new expectations and work to meet their modern aspirations. The propositions of modernization theory also sustain this finding on determinants as people struggle to cope with modern social economic realities as societies also move towards development. Traditional values and work-home life relationships are also re-examined and rational paths taken for modernity determined course of socioeconomic actions and goals. Within the subsisting systems, even other institutions of health, education and religion are also re-valued and reconstructed and outcomes of such re-valuations determine spousal movements as found in this article.

Academics, morality, peer influence and crime. These are four critical issues many children in Africa face in the current age. Parents are often concerned about how their children and wards will fare in contemporary societies in dealing with these challenges. Previous studies like those of Breivik, Olweus, Endersen, (2009), Mandara and Murray, (2006) and Simons, Simons and Wallace, (2004) have somewhat engaged these challenges and have made different findings which recognized the negative implications of parental absence for the children. Findings in the current article corroborate the earlier findings as could be seen in the quantitative and qualitative data presented above. These findings were also consistent with those of Wu, (1996) and Powell, (1993) who found and concluded that living in a single-parent family and absent parent family is a major predictor of delinquency and that children from single- 
parent homes are more likely to be delinquent and achieve less in life. This is also consistent with the findings of Sardon (2000) and Roussel (1989). This is also particularly so when globalization is factored into ASP and the family particularly children within such families (see Balogun and Olutayo (2005-2006), Akanle, 20I la).

According to Sardon, 2000; Davidson and Moore, 1996 and Roussel, 1989, evidences exist that family/spouses absenting from home for various reasons account for high divorce rates/failed/stressed marriages, fertility decline/fluctuations and general atypical family situations. This affects spouses at home and the absent ones in myriads of ways as presented above necessitating different types of coping strategies. While many turn to technology, religion and their work, some also adopt less popular means like extra-marital affairs to make up for the reduced coital frequency within marriage. In the age of HIV/ AIDS this should be a cause for concern especially as this method is seen as illegitimate within the traditional African family system. Once such spouses are caught, family pressures and disorganizations will likely be the consequence with negative implications for the family and the society at large. For the spouses who want to avoid extra-marital affairs, they usually increase their coital frequency and have sex unusually frequently when at home so they would not be staffed when absent until they return home for another ration of sex (see also Enel, Lagarde and Pison, 1994 for related findings).

\section{Conclusion}

This has explored the determinants and coping mechanisms of Absentee Spouse Phenomenon (ASP), in Ibadan Southwestern Nigeria and important findings have been made relative to determinants and coping strategies which are primarily economic with negative influences on children, spouses, the marriage and sexually behavior. When spouses are absent, it affects regularity of sexual relationships and can affect infidelity which may leads to contracting HIV/AIDS and other STIs. It leads to divorce, marriage disorganization and even population complications as family planning regimes become negatively affected with negative reproductive health behaviours. Children in ASP homes are more liable to crimes, delinquent behaviours and fair weakly in schools leading to more problems even within child and gender rights frameworks and constructs (see Adebayo and Akanle, 20I4, Akanle 2012 and Akanle 20l lb). The children from ASP homes also achieve less in life averagely and even parents expect less of them. ASP is thus a very central and critical issue that impacts the family, marriage and whole structure of society including population and development and must be properly understood and to and on time too. It is thus important for positive actions to be taken at personal, family and state levels.

Many of the respondents interviewed did not believe there can be any solution to ASP. To them, to say there is solution to ASP is to say people should not go out to work and should not go to school which is not possible in a nation on survival mode already infested with high level of illiteracy, unemployment and poverty. However, spouses should innovate more proactive ways of relocating together even if it means paying some immediate prices just for the health of the family and the nation. Employers and governments also need to institute policies that will in the nearest future aid family reunion to save allthe individual, the family and the nation for the common good. This article has drawn attention to this strongly and forcefully emerging pattern (ASP) in Nigeria and sub-Saharan Africa. This article is very wide in appeal and is particularly relevant within Migration Studies, Demography and Populations Studies, Development Studies, humanities, Public Policy, Sociology and even the Arts. The time has therefore come for more/further studies to explore more of the trajectories and ramifications of ASPespecially those left un/insufficiently explored in this article given the enormity of the problematic. With this article, we invite and welcome you on board!

\section{References}

Adebayo, A.A. and Akanle, O. 20I4. Gender and the Academy in Nigeria. African Journal for the Psychological Study of Social Issues. I7.I. Pp. 147-I54.

Aderonkola, T.B 2009. "Globalization Acculturation and the extinction of African culture". Journal of Faculty of Business and Social Sciences. 2(4).49-56.

Afolayan, A.A. 1994. "Population" pp. 123-135. in Ibadan Region. Edited by in M.O. Filani, F.O. Akinola and C.O. Ikporukpo. Ibadan. Rex Charles Publications.

Akande, C.R 2006. "Changing pattern of African culture" Journal of Social Science. 3.(I). 52-6I.

Akanle, O. 20I Ia. "Nigeria Culture and Identity in a Globalized World" pp. 27-4I. in The youth and the intangible cultural herigate in Nigeria. Edited by B. Owasanoye and O. AkanleLagos: Human Development Inititives and Centre for Black African Arts and Civilization.

Akanle, O. 20 I l b. "The Sociology of Gender Equality and Development and Development in Democratizing Nigeria". The Nigerian Journal of Sociology and Anthropology. 9.22-36. 
Akanle, O. 2012. "Childhood Construction, Child Rights and Development in Nigeria: Trajectories from the Yoruba of the South-western Nigeria". African Journal for the Psychological Studies of Social Issues. 15.(2).359-379.

Aldridge, A. And Levine, K. 200I. "Surveying the Social World Buckingham". Open University Press.

Areola, O. 1994. "The Spatial Growth of Ibadan City and its impact on the rural Hinterland" pp. 99 in Ibadan Region. Edited by M.O. Filani, F.O. Akintola and C.O. Ikporukpo Ibadan: Rex Charles Publication.

Balcom, D. A. 1998. "Absent fathers: Effects on abandoned sons". Journal of Men's Studies. 6. 283296.

Balogun, S.K. and Olutayo A.O. 2005/2006. Globalization and the African Family System Psychopathologie Africaine XXXIII (I). 77-92.

Biller, H. B., \& Meredith, D. L. 1972. "Invisible American father". Sexual Behavior. 2.16-22.

Breivik, Kyrre, Dan Olweus, and Inger Endersen. 2009. "Does the Quality of Parent-Child Relationships Mediate the Increased Risk for Antisocial Behaviour and Substance Use Among Adolescents in Single-Mother and Single-Father Families?" Journal of Divorce \& Remarriage, 50. 400-426.

Bruce, J. 1995. "The economics of motherhood. Families in focus: New perspectives on mothers, fathers, and children". New York: The population council.

Bruce, J., Lloyd, C.B, Leonard, A., Patrice, L.E and Duffy, N. 1995. "Families in focus: New perspectives on mothers, fathers, and children". New York: The Population Council.

Bryman, A. 2004. "Social Research Methods". Oxford: Oxford University Press.

Cavanagh, S.E. 2008. "Family structure, history and adolescent adjustment". Journal of family Issues. 29(7). 944-980.

Davidson, J.K. and Moore, N.B. 1996. "Marriage and Family: Change and continuity”. Boston, USA: Allyn and Bacon.

Desta, C.G. 2013. Fertility and maternal hours of work in Ethiopia: A Case study in the Amhara Region. African Population Studies. 27.2. 89- 104.

Downey, D. B., \& Powell, B. 1993. "Do children in single-parent households fare better living with same-sex parents? Journal of Marriage and Family, 55. 55- 7I.

Enel, C, Lagarde, E., and Pison, G. 1994. “The evaluation of surveys of sexual behaviour: a study of couples in rural Senegal". Health Transition Review. Supplement to 4. III - I 24.

Eweoya .O 2008. "Impact of single parenting on the academic performance of students". Benin: University of Benin.

Fagan, J. 1999. "Predictors of father and father figure involvement in pre-kindergarten Head Start". National Center on Fathers and Families. www.ncoff.gse.upen.edu 12/10/2012.

Findley, S. And Williams, L. 199I. "Women who go and women who stay: Reflections on family migration processes in a changing world". Working paper. 16. Geneva: ILO.

Gerald, C. O. 2008. "Absent fathers: its impact on the family". www.onlineNigeria.com/articules. I2/ $10 / 2012$

Giddens, A. 2000. "An Introduction to a Social Theorist". Oxford: Blackwell.

Gottfredson, M. R. and Hirschi, T. 1990. A General Theory of Crime. Stanford: Stanford University Press.

Haralambos, M and Holborn, M. 2008 "Sociology themes and perspectives". London: Harper Collins Publishers Limited.

Hettige, S.T., 1990, "From Dependant Housewives to Breadwinners", Second National Convention on Women's Studies, Colombo: CENWOR.

Isiugo-Abanihe, U.C. 2003. "Male Role and Responsibility in Fertility and Reproductive Health in Nigeria". Ibadan: Centre for Population Activities and Education for Development (CEPAED).

Lowenstein L.F. 2008. "Attachment Theory and Parental Alienation". England: Southern England Psychological Service. www.parentalalienation.info/public. 12/10/2012

Mandara, J., and Murray, C. 2006. "Father's absence and African American adolescent drug use". Journal of Divorce \& Remarriage, 46.. I- 12.

Muehlenberg B 2002. "The Cases for Two- Parent Family Part II". National Observer, 53. 48-58.

National Population Commission, 2010: "Census report in Nigeria". Abuja: National Population Commission.

Nicholson, L. 1997. "The myth of the traditional family" Feminism and Families. New York: Routledge.

Ogunremi G.O 1998. "An historical, cultural and socio economic study of an African city". Cargo Press.

Olutayo, A.O and Akanle, O 2009. "Fast food in Ibadan: an emerging consumption pattern". Africa. 79(2). 207-226.

Olutayo A.O and Omobowale A.O. 2006. "The youth and the family in transition in Nigeria". Review of Sociology. I I. I-I I.

Olutayo A.O. 1994. "Systemic source of working children in Africa: The case of Nigeria" Childhood. 4. 207-2II. 
Olutayo, A.O and Akanle O. 2007. "Modernity, MacDonaldisation and Family Values in Nigeria". The Nigerian Journal of Sociology and Anthropology. 5. 53-72.

Olutayo, A.O. 1996. "Violent Adolescents: A consideration of some predisposing factors to violent protests in Nigeria". African Notes: Bulleting of the Institute of African Studies. 20. (I2). 49-54.

Otite, O and Ogionwo, W. 2006. "An introduction to sociological studies". Ibadan: Heinemann Educational Books.

Patterson, J.M. 2002. "Integrating Family Resilience and Family Stress Theory". Journal of Marriage and Family. 64, (2). 349-360.

Price, C., \& Kunz, J. 2003. "Rethinking the paradigm of juvenile delinquency as related to divorce". Journal of Divorce and Remarriage, 39. (I/2). 109133.

Ritzer G 2008 "Sociological theory" London: McGraw-Hill Publisher

Rostow, W.W.1953."The Process of Economic Growth". .London: Oxford University Press.

Rostow, W.W.1960"The Stages of Economic Growth: A Comparative Manifesto" Cambridge:
Cambridge University Press

Roussel, L. 1989. "La famille incertaine”. Paris: Jacob. Rutayisire, P.C., Broekhuis, A., and Hooimeijer, P. 2013. Role Conflict in shaping Fertility Preferences in Rwanda. African Population Studies. 27.2. $105-117$.

Sardon, J-P. 2000. “Évolutions récentes de la démographie des pays développés". Population, $55(4-0) .729$

Sauer, R. J. 1979. "Absentee Father Syndrome". The Family Coordinator. 28. (2). 245-249.

Simons, R. L., Simons, L., and Wallace, E. 2004. "Families, delinquency, and crime: Linking society's most basic institution to antisocial behaviour". Los Angeles: Roxbury.

Wark, L. 2000. "Young Boys with Absent Fathers: A Child-Inclusive Intervention". Journal of Family Psychotherapy, I I(3). 63-68.

Wilfrid, F.R. 2007. "Globalisation's impacts on family life". http://wfiniruku.blogspot.com/2007/07/ globalisations-impacts-on-family-life.html.28/I/ 2013.

Wu, L.L. 1996. "Effects of marital instability, income, and income instability on the risk of premarital birth". American Sociological Review, 6I. 386-406. 